\title{
KEDUDUKAN PERATURAN KEBIJAKAN DALAM UNDANG-UNDANG ADMINISTRASI PEMERINTAHAN
}

\author{
Victor Imanuel w. Nalle \\ Fakultas Hukum Universitas Katolik Darma Cendika, Surabaya \\ Korespondensi: victor.imanuel@ukdc.ac.id
}

\begin{abstract}
Abstrak
Prinsip diskresi adalah prinsip yang penting sebagai panduan bagi pemerintah untuk mengambil tindakan. Sebagaimana halnya hakim yang tidak boleh menolak perkara dengan alasan tidak ada hukumnya, maka pemerintah pun tidak dapat menolak mengambil tindakan dalam keadaan genting dengan alasan tidak ada dasar hukumnya. Produk hukum yang merupakan keluaran dari diskresi tersebut berupa peraturan kebijakan (beleidsregels atau policy rules). Walaupun dalam praktik penyelenggaraan pemerintahan seringkali menggunakan peraturan kebijakan tetapi belum ada peraturan perundang-undangan yang mengatur penggunaan peraturan kebijakan sebagai bentuk diskresi. Undang-Undang Nomor 30 Tahun 2014 tentang Administrasi Pemerintahan sebagai "payung" bagi hukum administrasi negara di Indonesia juga tidak mengatur peraturan kebijakan. Tulisan ini akan mengkaji konsep peraturan kebijakan untuk diintrodusir ke dalam UU Administrasi Pemerintahan agar terdapat pengaturan yang utuh dari diskresi hingga bentuk-bentuk dari diskresi, salah satunya peraturan kebijakan.
\end{abstract}

Kata-kata Kunci: Diskresi; Peraturan Kebijakan; UU Administrasi Pemerintahan.

\begin{abstract}
The principle of discretion is an important principle as a guide for the government to take action. As in the case of judges who may not refuse a case with no legal reason, then the government can't refuse to take action in conjuncture with the reason no legal basis. Although in practice governance policies often use policy rules, but there is no legislation governing the use of policy rules as a form of discretion. Act No. 30 of 2014 on Public Administration as an "umbrella" for administrative law in Indonesia is not set policy rules. This paper will review the policy rules concept to be introduced into the reform of Public Administration Act. The reform of Public Administration Act will make the Act have the whole concept of discretion.
\end{abstract}

Key Words: Discretion; Policy Rule; Public Administration Act. 


\section{PENDAHULUAN}

Diundangkannya Undang-Undang Nomor 30 Tahun 2014 tentang Administrasi Pemerintahan (UU Administrasi Pemerintahan) akhirnya menutup masa kerja DPR RI Periode 2009 - 2014 sebagai salah satu UndangUndang yang disahkan di akhir periode. Menteri Pendayagunaan Aparatur Negara menyambut baik disahkannya UU Administrasi Pemerintahan dan menyebutnya sebagai akhir penantian bagi setiap aparatur negara.

Menteri Pendayagunaan Aparatur Negara dan Reformasi Birokrasi memberikan argumentasi bahwa UU Administrasi Pemerintahan nantinya menjadi landasan yuridis bagi aparatur negara dalam melakukan tindakan pemerintahan. UU Administrasi Pemerintahan memberikan kriteria yang jelas bagi aparatur negara agar tidak terjebak dalam penyalahgunaan wewenang. ${ }^{1}$ Tentunya argumentasi tersebut perlu ditanggapi dengan positif karena sebagian besar tindak pidana korupsi yang dilakukan oleh aparatur negara terjadi karena adanya unsur penyalahgunaan wewenang dalam melakukan tindakan pemerintahan.

Tentunya UU Administrasi Pemerintahan tidak dapat diterima taken for granted. UU Administrasi Pemerintahan menjadi semacam "payung" bagi Undang-Undang lain yang terkait dengan administrasi pemerintahan. Oleh karena itu seharusnya UU Administrasi Pemerintahan mengatur secara komprehensif aspek-aspek administrasi pemerintahan sehingga tidak terjadi "kekosongan" atau norma yang "kabur" dalam menjalankan pemerintahan. Namun jika dianalisis secara kritis, UU Administrasi Pemerintahan menyisakan ruang kosong pengaturan salah satu instrumen yang seringkali digunakan oleh aparatur negara, yaitu peraturan kebijakan.

Pemerintah, dalam praktiknya, seringkali menggunakan peraturan kebijakan sebagai dasar hukum dalam pelaksanaan kebijakan. Peraturan kebijakan yang dibuat oleh pemerintah bentuknya bukan berupa salah satu jenis peraturan perundang-undangan yang dikenal dalam Pasal 7 UU No. 12 Tahun 2011. Namun dalam praktik seringkali peraturan kebijakan memiliki kekuatan mengikat yang sama dengan peraturan perundang-undangan.

Peraturan kebijakan memiliki substansi dan kekuatan mengikat yang tidak berbeda dengan peraturan perundang-undangan, tetapi arus besar pemikiran hukum tidak mengkategorikan peraturan kebijakan sebagai peraturan perundangundangan. Padahal, menurut Attamimi, peraturan kebijakan jika dilihat dari bentuk dan formatnya seringkali sama dengan peraturan perundangundangan, lengkap dengan pembukaan

Anonim, 'RUU Adpem Disahkan, Tak Ada Lagi Kriminalisasi Kebijakan' (2014) <http:// www.menpan.go.id/berita-terkini/2666-ruu-adpem-disahkan-tak-ada-lagi-kriminalisasikebijakan> diakses 19 November 2014. 
berupa konsiderans "menimbang”, dasar hukum "mengingat", batang tubuh berupa pasal-pasal, bagian, bab, serta penutup yang serupa dengan peraturan perundang-undangan. ${ }^{2}$ Praktik tersebut menunjukkan bahwa belum terdapat kejelasan tentang format dan substansi peraturan kebijakan. Peraturan kebijakan disebut bukanlah peraturan perundang-undangan tetapi sifat substansinya seringkali merupakan norma pengaturan untuk umum yang seharusnya diatur melalui peraturan perundang-undangan. Kondisi seperti ini dalam praktiknya tentu dapat menimbulkan ketidakpastian hukum, terutama dalam hal kekuatan mengikatnya. Oleh karena itu seharusnya peraturan kebijakan diatur dalam Undang-Undang untuk mencegah penggunaan peraturan kebijakan secara sewenang-wenang.

Tulisan ini akan menganalisis UU Administrasi Pemerintahan, khususnya pengaturan konsep diskresi. Konsep diskresi tersebut tidak dapat dilepaskan dari peraturan kebijakan sebagai "produk" diskresi. Sebagai kajian doktrinal, tulisan ini akan menggunakan pendekatan konseptual dan pendekatan perbandingan. Pendekatan konseptual akan difokuskan pada konsep diskresi dan konsep peraturan kebijakan. Pendekatan perbandingan akan digunakan untuk menganalisis pengaturan peraturan kebijakan di negara lain yang telah memiliki Undang-
Undang serupa, yaitu Belanda dan Amerika Serikat. Oleh karena itu bahan hukum yang digunakan dalam kajian ini bukan hanya UU Administrasi Pemerintahan tetapi juga Algemene Wet Bestuursrecht (AWB) dan Admnistrative Procedure Act (APA).

\section{PEMBAHASAN}

\section{Diskresi dalam UU Administrasi Pemerintahan}

Naskah Akademik RUU Administrasi Pemerintahan tidak memberikan ratio legis yang komprehensif terhadap pengaturan konsep diskresi. Naskah Akademik RUU Administrasi Pemerintahan menyatakan sebagai berikut: ${ }^{3}$

Diskresi merupakan kewenangan pejabat administrasi pemerintahan untuk mengambil keputusan pemerintahan yang bebas karena belum diaturnya suatu hal tertentu dalam peraturan perundang-undangan yang ada. Diskresi dapat memberikan manfaat yang positif bagi terselenggaranya kegiatan pemerintahan yang berkesinambungan dan tidak terhambat oleh kekosongan hukum yang ada, namun demikian diskresi dapat menimbulkan dampak negatif apabila di dalam pelaksanaannya justru melanggar rambu-rambu hukum yang ada serta bertentangan dengan norma-norma yang ada di masyarakat dan bertentangan dengan kepentingan umum.

2 A. Hamid S.Attamimi, 'Hukum tentang Peraturan Perundang-undangan dan Peraturan Kebijakan (Hukum Tata Pengaturan)' (Pidato Purna Bakti Guru Besar Tetap Universitas Jakarta 1993) 13.

3 Kementerian Pendayagunaan Aparatur Negara dan Reformasi Birokrasi, Naskah Akademik Rancangan Undang-Undang Administrasi Pemerintahan (Kemenpan RB 2014) 54. 
Berdasarkan definisi tersebut maka diskresi dalam Naskah Akademik RUU Administrasi Pemerintahan timbul karena adanya kekosongan hukum. Namun pengaturan diskresi lebih lanjut dalam UU Administrasi Pemerintahan mengalami perluasan.

Diskresi secara khusus diatur dalam Bab VI UU Administrasi Pemerintahan. Sebelumnya Pasal 1 mendefinisikan diskresi sebagai Keputusan dan/atau Tindakan yang ditetapkan dan/atau dilakukan oleh Pejabat Pemerintahan untuk mengatasi persoalan konkret yang dihadapi dalam penyelenggaraan pemerintahan dalam peraturan perundang-undangan yang memberikan pilihan, tidak mengatur, tidak lengkap atau tidak jelas, dan/atau adanya stagnasi pemerintahan. Definisi tersebut memberikan unsur-unsur diskresi, antara lain:

1. Berupa keputusan dan/atau tindakan;

2. Ditetapkan dan/atau dilakukan;

3. Dilakukan oleh pejabat pemerintahan;

4. Untuk mengatasi persoalan konkret dalam penyelenggaraan pemerintahan;

5. Diskresi tersebut dilakukan dalam hal (bersifat alternatif):

a. Peraturan perundang-undangan memberikan pilihan;

b. Peraturan perundang-undangan tidak mengatur; c. Peraturan perundang-undangan tidak lengkap atau tidak jelas;

d. Adanya stagnasi pemerintahan. ${ }^{4}$

Definisi tersebut menunjukkan bahwa diskresi tidak hanya berupa keputusan tetapi dapat juga berupa tindakan atau keputusan yang disertai dengan tindakan. Tindakan dalam konteks ini dimaknai UU Administrasi Pemerintahan sebagai perbuatan Pejabat Pemerintahan atau penyelenggara negara lainnya untuk melakukan dan/atau tidak melakukan perbuatan konkret dalam rangka penyelenggaraan pemerintahan (Pasal 1 angka 8). Dengan demikian diskresi dapat memiliki 2 (dua) bentuk. Pertama, keputusan tata usaha negara. Kedua, tindakan nyata pemerintahan atau yang dikonsepkan oleh Utrecht ${ }^{5}$ sebagai perbuatan pemerintah yang berdasarkan fakta atau perbuatan yang bukan perbuatan hukum atau perbuatan tanpa akibat yang diatur oleh hukum. Oleh karena itu, jika mengacu pada definisi UU Administrasi Pemerintahan, diskresi juga berupa tindakan faktual yang tidak memiliki akibat hukum (lihat Gambar 1).

Stagnasi pemerintahan merupakan kondisi tidak dapat dilaksanakannya aktivitas pemerintahan sebagai akibat kebuntuan atau disfungsi dalam penyelenggaraan pemerintahan, misalnya bencana alam atau gejala politik. Lihat Penjelasan Pasal 22 ayat (2) UU Administrasi Pemerintahan.

5 Jum Anggriani, Hukum Administrasi Negara (Graha Ilmu 2012) 106. 
Gambar 1. Alur Diskresi Berdasarkan UU Administrasi Pemerintahan

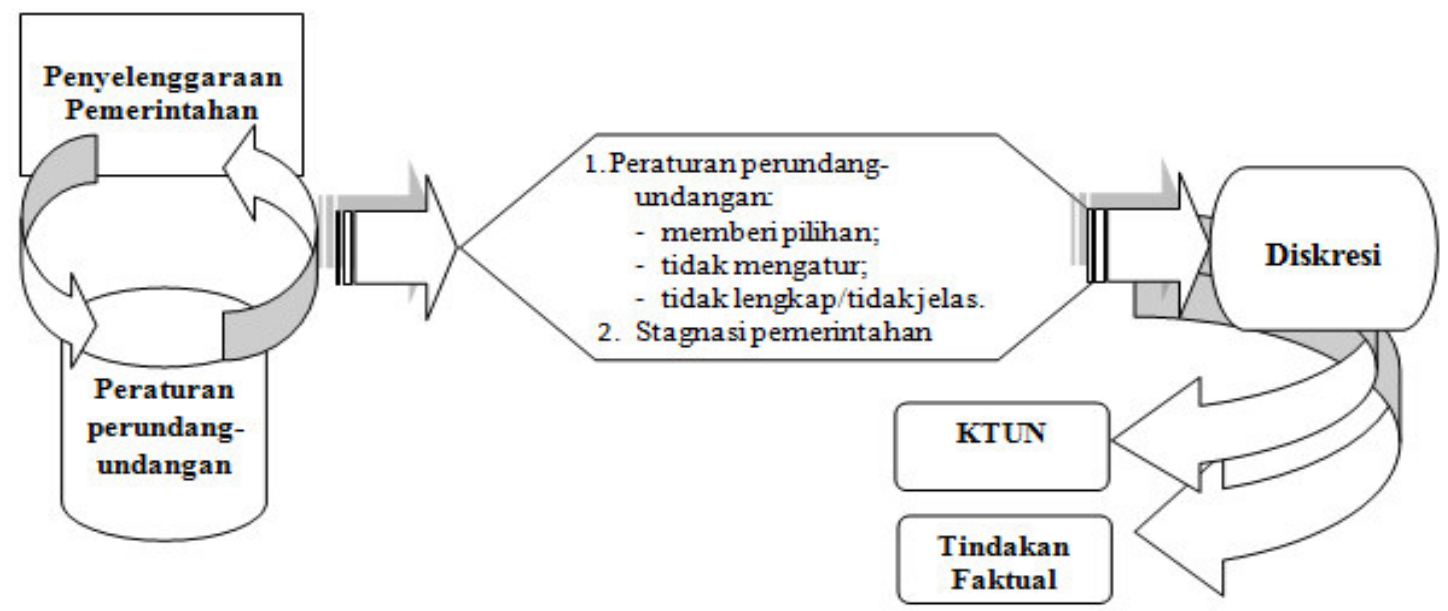

Jika dikaitkan dengan berbagai pendapat yang dikemukakan ahli, terlihat bahwa konsep diskresi dalam UU Administrasi Pemerintahan telah mencoba mensintesiskan berbagai pendapat. Menurut Darumurti, misalnya, diskresi dapat didefinisikan sebagai bentuk wewenang pada badan atau pejabat pemerintah yang memungkinkan mereka untuk melakukan pilihan-pilihan dalam mengambil tindakan hukum dan/atau tindakan faktual dalam lingkup tindakan pemerintah. ${ }^{6}$ Diskresi dimiliki oleh pemerintah karena pemerintah harus aktif berperan mencampuri bidang kehidupan sosial ekonomi masyarakat (public service) yang mengakibatkan pemerintah tidak boleh menolak untuk mengambil keputusan ataupun bertindak dengan dalih terjadi kekosongan pengaturan hukum. Pemerintah diberikan kewenangan untuk campur tangan dalam lapangan kehidupan masyarakat dan pemerintah dituntut untuk bertindak aktif di tengah dinamika kehidupan masyarakat. ${ }^{7}$

Pandangan yang tidak jauh berbeda juga disampaikan oleh Kranenburg. Menurut Kranenburg, sebagaimana dikutip Hadjon, kebebasan yang dimaksud dalam diskresi adalah kebebasan karena tidak ada pengaturan. Diskresi perlu dilakukan karena Undang-Undang tidak merinci apa yang terjadi secara konkret dan hal itulah yang harus dicari sendiri oleh pemerintah. Oleh karena itu tetap ada keterikatan pada peraturan perundangundangan saat tindakan pemerintah dilakukan atas dasar diskresi. ${ }^{8}$

Konsep diskresi yang penting adalah bahwa ketika diskresi digunakan dalam pemerintahan maka berlaku perlindungan hukum kepada badan/ pejabat yang bersangkutan. Perlindungan hukum bagi badan/ pejabat yang melakukan diskresi adalah jaminan imunitas dari tindakan judicial

Krishna D. Darumurti, Kekuasaan Diskresi Pemerintah (Citra Aditya Bakti 2012) 57-58.

Ibid.

Philipus M.Hadjon, Pengertian Dasar tentang Tindak Pemerintahan (Djumali 1985) 45. 
review oleh hakim. Hal ini terkenal dengan adagium "kebijakan tidak dapat diadili”. Dalam hukum tata negara atau hukum administrasi Amerika Serikat, isu pengujian terhadap kebijakan termasuk dalam kategori political question atau nonjusticiable issue yaitu pengadilan akan menahan diri untuk tidak melakukan intervensi (selfrestraint) atas kekuasaan pemerintah yang sifatnya sangat teknikal. Menurut Cass R. Sunstein, sebagaimana dikutip Darumurti, dasar pertimbangan pengadilan untuk tidak melakukan intervensi terhadap tindakan diskresi pemerintah adalah argumen pragmatisme, yaitu: "judges lack expertise and they are not politically accountable". ${ }^{9}$

Jika diskresi timbul karena tidak adanya pengaturan maka seharusnya bentuk dari diskresi tidak dapat berupa peraturan perundang-undangan. Pasal 8 ayat (2) Undang-Undang Nomor 12 Tahun 2011 tentang Pembentukan Peraturan Perundang-undangan menyatakan bahwa peraturan yang tidak termasuk dalam hierarki peraturan perundang-undangan [Pasal 7 ayat (1) $]^{10}$ mempunyai kekuatan hukum mengikat sepanjang diperintahkan oleh peraturan perundang-undangan yang lebih tinggi atau dibentuk berdasarkan kewenangan. ${ }^{11}$ Oleh karena itu, misalnya, Peraturan Gubernur yang dibentuk atas dasar diskresi (tanpa adanya atribusi atau delegasi atau mandat) seharusnya tidak dikategorikan sebagai peraturan perundangundangan. Lalu dikategorikan sebagai apakah produk hukum dari diskresi tersebut?

UU Administrasi Pemerintahan hanya memasukkan KTUN dan tindakan faktual pemerintah sebagai bentuk diskresi, walaupun tindakan faktual pada hakikatnya tidak dapat dikategorikan sebagai produk hukum pemerintah karena tidak menimbulkan akibat hukum. KTUN sebagai produk hukum dari diskresi berimplikasi pada sifat diskresi. Dengan demikian diskresi karena, misalnya, kekosongan hukum hanya dapat dibentuk dalam KTUN yang sifatnya konkrit, individual, dan final. ${ }^{12}$ Padahal diskresi juga harus diikuti dengan produk hukum yang bersifat umum dan abstrak karena implikasi kekosongan hukum bersifat umum, bukan individual.

Secara teoretis, ilmu hukum administrasi mengenal konsep peraturan kebijakan sebagai produk hukum dari diskresi. Namun peraturan kebijakan bukanlah peraturan perundang-undangan sehingga implikasi mengikatnya tidak sama

\footnotetext{
9 Krishna D. Darumurti, Op.Cit. 36-37.
}

10 Hierarki tersebut mencakup UUD NRI 1945, Ketetapan MPR, Undang-Undang/Peraturan Pemerintah Pengganti Undang-Undang, Peraturan Pemerintah, Peraturan Presiden, Peraturan Daerah Provinsi, Peraturan Daerah Kabupaten/Kota

11 Kewenangan, jika merujuk pada Pasal 11 UU No. 30 Tahun 2014, hanya dapat diperoleh melalui atribusi, delegasi, dan mandat.

12 Lihat UU No. 5 Tahun 1986 tentang Peradilan Tata Usaha Negara sebagaimana telah diubah dengan Undang-Undang Nomor 9 Tahun 2004 dan Undang-Undang Nomor 51 Tahun 2009. 
dengan peraturan perundangundangan. Namun pada praktiknya, kekuatan mengikat peraturan kebijakan sebenarnya telah mengalami perluasan. Peraturan kebijakan, menurut Bagir Manan, tidak secara langsung mengikat secara hukum walaupun tetap mengandung relevansi hukum. Kekuatan mengikatnya hanya bagi badan atau pejabat administrasi negara sendiri. Meskipun ketentuan dalam peraturan kebijakan biasanya akan menyangkut masyarakat umum secara tidak langsung. Sebagai contoh adalah suatu Juklak pelaksanaan tender. Juklak tersebut hanya berisi ketentuan tata cara administrasi negara dalam menyelenggarakan tender tetapi ketentuan-ketentuan tersebut secara tidak langsung akan terkait dengan calon peserta tender. ${ }^{13}$ Walaupun sifat peraturan kebijakan pada hakikatnya tidak mengikat, tetapi pada praktiknya peraturan kebijakan memegang peranan penting dalam penyelenggaraan pemerintahan. Dengan peranan yang penting dalam penyelenggaraan pemerintahan, seharusnya UU Administrasi Pemerintahan mengatur peraturan kebijakan, tetapi pada kenyataannya justru sebaliknya. Padahal peraturan kebijakan tidak dapat dilepaskan dari diskresi yang diatur dalam UU Administrasi Pemerintahan.

Praktik dalam pemerintahan menunjukkan bahwa berbagai bentuk peraturan kebijakan digunakan dalam penyelenggaraan pemerintahan. Namun berbagai bentuk peraturan kebijakan tersebut tidak diatur kedudukannya sebagai peraturan kebijakan. Menurut Jimly Asshiddiqie, dalam praktiknya di Indonesia, peraturan kebijakan dapat dibuat dalam bentuk-bentuk seperti: ${ }^{14}$

a. Surat edaran ${ }^{15}$, contoh: Surat Edaran Bank Indonesia;

b. Surat perintah ${ }^{16}$ atau instruksi, contoh: Instruksi Presiden;

c. Pedoman Kerja atau Manual;

d. Petunjuk Pelaksanaan (Juklak);

e. Petunjuk Teknis (Juknis);

f. Buku Panduan atau "guide" (guidance);

g. Kerangka Acuan atau Term of Reference (TOR);

h. Desain Kerja atau Desain Proyek (Project Design).

Selain bentuk-bentuk yang dikemukakan Jimly Asshiddiqie, Bagir Manan juga memberikan contoh bentuk peraturan kebijakan yang pernah digunakan dalam administrasi

13 Bagir Manan dan Kuntana Magnar, Beberapa Masalah Hukum Tata Negara Indonesia (Alumni 1997) 170.

14 Jimly Asshiddiqie, Perihal Undang-Undang (Rajawali Pers 2010) 274.

15 Pasal 1 Angka 43 Permendagri No. 55 Tahun 2010 tentang Tata Naskah Dinas di Lingkungan Kementerian Dalam Negeri mendefinisikan Surat Edaran sebagai naskah dinas yang berisi pemberitahuan, penjelasan dan/atau petunjuk cara melaksanakan hal tertentu yang dianggap penting dan mendesak.

16 Pasal 1 Angka 47 Permendagri No. 55 Tahun 2010 mendefinisikan Surat Perintah sebagai naskah dinas dari atasan yang ditujukan kepada bawahan yang berisi perintah untuk melaksanakan pekerjaan tertentu.

17 Bagir Manan, 'Peraturan Kebijakan' (2008) Varia Peradilan 1, 16-17. 
pemerintahan. Beberapa bentuk tersebut antara lain: ${ }^{17}$

1. Peraturan kebijakan yang berbentuk peraturan.

Sebagai contoh peraturan kebijakan yang berbentuk peraturan adalah Permendagri No.4 Tahun 1976 tentang Tata Cara Pelaksanaan Penyerahan Urusan-urusan dari Daerah Tingkat I kepada Daerah Tingkat II.

2. Peraturan kebijakan yang berbentuk keputusan.

Peraturan kebijakan yang berbentuk keputusan bukanlah KTUN. Sifat substansinya berbeda dengan KTUN yang bersifat konkret, individual, dan final. Contoh peraturan kebijakan berbentuk keputusan adalah Keppres No.29 Tahun 1984 tentang Pelaksanaan Anggaran Pendapatan dan Belanja Negara.

3. Surat Edaran.

Administrasi negara sebagia pelaksana suatu kebijakan tidak dapat begitu saja mengenyampingkan surat edaran. Karena, walaupun surat edaran bukan merupakan suatu ketentuan hukum tetapi merupakan manifestasi dari kebebasan bertindak yang melekat pada administrasi negara. Dalam administrasi negara juga berlaku asas mematuhi keputusan sendiri dan menjalankan dengan sungguhsungguh kebijakan yang ditetapkan secara hirarkis dalam lingkungan administrasi negara yang bersangkutan.

4. Instruksi.
Instruksi merupakan suatu bentuk keputusan yang bersifat hirarkis, berlaku bagi jajaran administrasi negara di bawah pembuat instruksi. Berdasarkan isinya, terdapat instruksi yang merupakan peraturan kebijakan dan ada juga yang bukan peraturan kebijakan. Instruksi tentang kebijakan konkret tertentu (khusus) tidak dapat dimasukkan sebagai peraturan kebijakan. Instruksi untuk melaksanakan tugas tertentu bukanlah peraturan kebijakan. Instruksi akan menjadi peraturan kebijakan jika disertai dengan ketentuan yang bersifat umum.

5. Pengumuman tertulis.

Sekitar tahun 1945-1949 cukup banyak dijumpai berbagai macam pengumuman atau maklumat. Tetapi maklumat yang ditetapkan pada waktu itu tidak selalu bersifat peraturan kebijakan. Perlu dibedakan kedudukan Presiden dan Wakil Presiden saat membuat pengumuman atau maklumat, apakah sebagai administrasi negara atau pemegang kekuasaan negara. Maklumat Nomor X Tahun 1945 (16 Oktober 1945), menurut Bagir Manan, harus dipahami sebagai keputusan negara bukan administrasi negara. Pengumuman sebagai peraturan kebijakan juga harus berbentuk tertulis dan bersifat umum.

\section{Peraturan Kebijakan sebagai Produk Diskresi \\ Sub-bahasan sebelumnya telah} menjelaskan hakikat diskresi sebagai 
tindakan yang diambil pemerintah untuk mengatasi kekosongan hukum sebagai upaya mengatasi masalah penyelenggaraan pemerintahan. Undang-Undang yang mengatur administrasi pemerintahan di Belanda dan Amerika Serikat mengatur bagaimana diskresi tersebut kemudian berujung pada peraturan kebijakan sebagai produknya.

Peraturan kebijakan di Belanda, yang dikenal dengan istilah beleidregels, telah diatur dalam Undang-Undang Administrasi Pemerintahan atau Algemene Wet Bestuursrecht (AWB), yang juga diterjemahkan dalam bahasa Inggris menjadi General Administrative Law Act (GALA). Peraturan kebijakan diatur dalam Artikel 1:3(4) AWB sebagai berikut:

Onder beleidsregel wordt verstaan: een bij besluit vastgestelde algemene regel, niet zijnde een algemeen verbindend voorschrift, omtrent de afweging van belangen, de vaststelling van feiten of de uitleg van wettelijke voorschriften bij het gebruik van een bevoegdheid van een bestuursorgaan.

(Terjemahan GALA: 'Policy rule' means an order, not being a generally binding regulation, which lays down a general rule for weighing interests, determining facts or interpreting statutory regulations in the exercise of a power of an administrative authority.)

Besluit atau order [sebagaimana disebut oleh Artikel 1:3(4)] dalam Artikel 1:3(1) didefinisikan sebagai "sebuah keputusan tertulis dari suatu badan administrasi bilamana keputusan tertulis tersebut menetapkan suatu tindakan hukum publik." Lengkapnya Artikel 1:3(1) menyatakan: "Onder besluit wordt verstaan: een schriftelijke beslissing van een bestuursorgaan, inhoudende een publiekrechtelijke rechtshandeling ('Order' means a written decision of an administrative authority constituting a public law act).

Beleidsregel jika mengacu pada AWB menitikberatkan perannya sebagai peraturan untuk menafsir regulasi. Regulasi pada umumnya ditafsirkan karena adanya norma yang kabur. Selain itu beleidsregel, menurut AWB, haruslah berupa besluit. Oleh karena itu AWB secara langsung telah memberikan batasan bahwa peraturan kebijakan haruslah berbentuk tertulis.

Van der Vlies, salah seorang ahli perundang-undangan Belanda, mengidentifikasi peraturan kebijakan di Belanda yang lebih banyak dibuat oleh menteri tidak bersumber pada UndangUndang. Contoh peraturan menteri yang merupakan peraturan kebijakan adalah keputusan dan surat edaran mengenai pajak, peraturan subsidi, surat edaran mengenai orang asing serta surat edaran mengenai pelaksanaan Undang-Undang Tunjangan Sosial. ${ }^{18}$ Van der Vlies kemudian membagi peraturan kebijakan di Belanda, pada praktiknya, ke dalam dua kategori, yaitu:

18 I.C. van der Vlies, Buku Pegangan Perancang Peraturan Perundang-undangan (Direktorat Jenderal Peraturan Perundang-undangan Departemen Hukum dan Hak Asasi Manusia RI 2005) 192. 
a. Peraturan kebijakan karena kewenangan membuat beschikking yang timbul karena kewenangan menteri, dari suatu Undang-Undang, untuk membentuk beschikking. Namun Undang-Undang tidak merinci norma-norma apa saja yang perlu diperhatikan oleh menteri dalam membuat suatu keputusan. Oleh karena itu, seseorang tidak dapat mengetahui dari UndangUndang tersebut dalam hal apa ia mempunyai atau tidak mempunyai hak atas keputusan yang diinginkannya sehingga ia berada dalam ketidakpastian hukum.

b. Peraturan kebijakan karena kewenangan membuat keputusan lainnya, yang pada umumnya terkait dengan kewenangan yang timbul dari Undang-Undang tentang anggaran negara. Peraturan kebijakan ini timbul karena kondisikondisi dalam konteks penggunaan dana anggaran negara memerlukan peraturan kebijakan untuk memudahkan pengelolaan dana tersebut. ${ }^{19}$

Menurut Albertjan Tollenaar, peraturan kebijakan merupakan sebuah terobosan untuk mengatasi hambatan dari asas legalitas yang berakibat pada inefisiensi dan ketidakefektifan dalam pengambilan keputusan pada masyarakat yang berubah dengan cepat. Menurut Tollenaar:
The principle of legality is regarded more and more as an obstacle for effective, efficient decision-making that serves the general interest. Some authors state that it is the current, fast changing society that impedes the standardizing power of legislation. The way of reasoning is then: the society changes so fast that the legislative procedure is simply too slow to adapt rules and regulations to this new societal situation. ${ }^{20}$

Lebih lanjut Tollenaar mengemukakan bahwa persyaratan yang paling penting dalam membentuk peraturan kebijakan adalah bahwa peraturan kebijakan harus diterapkan oleh badan administratif yang kompeten. Badan administratif yang kompeten adalah badan administratif memiliki wewenang untuk membuat keputusan individual. Jadi, misalnya, pemerintah kota yang kompeten untuk mengeluarkan izin bangunan juga memiliki kompetensi untuk menetapkan peraturan kebijakan yang berkaitan dengan izin tersebut. ${ }^{21}$

Pengaturan peraturan kebijakan dalam AWB berdampak pada pelaksanaan peraturan yang tidak termasuk peraturan perundangundangan, atau yang dikategorikan Tollenaar sebagai soft law. Kodifikasi peraturan kebijakan di Belanda membuat aplikasi soft law dalam pengambilan keputusan yang bersifat individual menjadi kompleks. Semenjak parlemen Belanda mendefinisikan peraturan kebijakan, hal tersebut juga

\footnotetext{
Ibid. 193-197.

Albertjan Tollenaar, 'Soft Law and Policy Rules in the Netherlands' (2012) Netherlands Administrative Law Library 1, 4.

21 Ibid.
} 
berakibat pada implikasinya karena peraturan kebijakan menjadi memiliki kekuatan yang sama dengan peraturan perundang-undangan (hard law). Oleh karena itu badan-badan administratif dalam bertugas harus bertindak sesuai dengan peraturan kebijakan. Penyimpangan hanya diperbolehkan dalam 'keadaan khusus'. ${ }^{22}$

Amerika Serikat juga mengatur peraturan kebijakan di dalam Administrative Procedure Act (APA). Namun pengaturan peraturan kebijakan di Amerika Serikat tidak komprehensif sebagaimana pengaturan beleidsregel dalam AWB. APA tidak menyebut secara eksplisit terminologi policy rule, sebagaimana AWB menyebutnya dengan terminologi beleidregel. Namun apapun peraturan yang substansinya adalah kebijakan (policy), berdasarkan APA, merupakan suatu peraturan (rule). Proses pembuatan peraturan (rule making) itu pula yang diatur dalam APA. Rule, menurut Section 551(4) APA, berarti:

...the whole or a part of an agency statement of general or particular applicability and future effect designed to implement, interpret, or prescribe law or policy or describing the organization, procedure, or practice requirements of an agency and includes the approval or prescription for the future of rates, wages, corporate or financial structures or reorganizations thereof, prices, facilities, appliances, services or allowances therefore or of valuations, costs, or accounting, or practices bearing on any of the foregoing.
Berdasarkan ruang lingkup peraturan yang luas tersebut tidak semua cakupan peraturan harus mengikuti prosedur pembuatan peraturan yang diatur oleh APA. Beberapa peraturan dikecualikan dari prosedur notice and comment. Beberapa peraturan yang dikecualikan tersebut, berdasarkan Section 553(b)(A) adalah interpretative rules dan general statements of policy. Beberapa bentuk peraturan ini serupa dengan konsep peraturan kebijakan di Indonesia, misalnya juklak, juknis, dan surat edaran. Praktik administrasi pemerintahan di Inggris bahkan menunjukkan berbagai variasi bentuk peraturan kebijakan yang digunakan, yaitu:

a. Procedural rules, yaitu aturan yang memberikan panduan prosedur bagi pemohon dalam mengajukan permohonan.

b. Interpretative guides, aturan yang menjelaskan bagaimana seharusnya aturan hukum yang lebih tinggi ditafsirkan dan dilaksanakan.

c. Instructions to officials, aturan yang berisi instruksi bagi bawahan dari pejabat yang mengeluarkan peraturan kebijakan tersebut.

d. Prescriptive/evidential rules, yang lebih menitikberatkan perspektif posisi aturan tersebut sebagai alat bukti dalam mengukur tindakan pejabat administrasi. Oleh karena itu, bentuk atau jenis peraturan kebijakan ini lebih dilihat dari kemanfaatannya dalam aspek tanggung gugat pemerintah.

22 Ibid. 
e. Commendatory rules, umummnya dan utamanya aturan ini berisi rekomendasi untuk melakukan suatu tindakan.

f. Voluntary codes, merupakan aturan yang diciptakan sebagai kode etik untuk dipatuhi di internal organisasi.

g. Rules of practice, management, or operation; salah satu contoh peraturan kebijakan jenis ini adalah peraturan kebijakan yang meringankan pajak jika wajib pajak memenuhi syarat tertentu atau melakukan tindakan-tindakan tertentu yang diinginkan oleh pemerintah.

h. Consultative devices and administrative pronouncements, jenis atau bentuk peraturan kebijakan ini menyerap bentuk peraturan kebijakan yang tidak termasuk ke dalam bentuk-bentuk peraturan kebijakan lainnya tetapi memiliki signifikansi terhadap kasus-kasus individual.

Attorney General's Manual on the Administrative Procedure Act mendefinisikan interpretative rules sebagai: “...rules or statements issued by an agency to advise the public of the agency's construction of the statutes and rules which it administers." General statements of policy didefinisikan sebagai "statements issued by an agency to advise the public prospectively of the manner in which the agency proposes to exercise a discretionary power." 23 Definisi-definisi tersebut sekaligus menunjukkan bahwa policy rule di Amerika Serikat merupakan implikasi dari discretionary power yang dimiliki oleh pemerintah dalam menjalankan pemerintahan. ${ }^{24}$

Pengaturan peraturan kebijakan di Belanda dan Amerika Serikat menunjukkan karakter peraturan kebijakan, yaitu tidak diperlukannya pendelegasian wewenang dari UndangUndang untuk membentuk peraturan kebijakan. Walaupun tidak ada pendelegasian wewenang untuk membentuknya, tetapi praktik pemerintahan menunjukkan perlunya wewenang pejabat pemerintahan memberikan interpretasi terhadap Undang-Undang yang tidak jelas normanya.

Interpretasi tersebut bisa menjadi sangat diperlukan karena perlunya kesamaan pandangan eksekutif dalam menyelenggarakan pemerintahan. Ketiadaan kesamaan pandangan dalam menafsirkan Undang-Undang dapat menyebabkan macetnya pemerintahan.

23 Jacob E. Gersen, Legislative Rules Revisited, (2007) 74 The University of Chicago Law Review 1705, 1709.

24 Menurut Jack M. Beermann, suatu peraturan disebut sebagai interpretative rules jika aturan tersebut tidak menambahkan hal yang baru di dalam peraturan perundang-undangan yang sebelumnya telah ada. Peraturan tersebut haruslah sekedar menginformasikan kepada publik sudut pandang badan administrasi terhadap pengertian atau maksud dari suatu peraturan perundang-undangan. Sedangkan general statements of policy menginformasikan kepada publik tentang pandangan badan administrasi terhadap kebijakannya tetapi tidak bermaksud untuk menambahkan atau meniru peraturan perundang-undangan yang telah ada sebelumnya. Lihat Jack M. Beermann, Administrative Law (Aspen Publishers 2010) 86-87. 
Norma yang kabur justru dapat inilah yang makin menunjukkan mempengaruhi pejabat pemerintahan hubungan diskresi dan peraturan dalam mengambil tindakan. Konteks kebijakan (lihat Gambar 2).

Gambar 2. Alur Terbentuknya Peraturan Kebijakan di Belanda dan Amerika Serikat

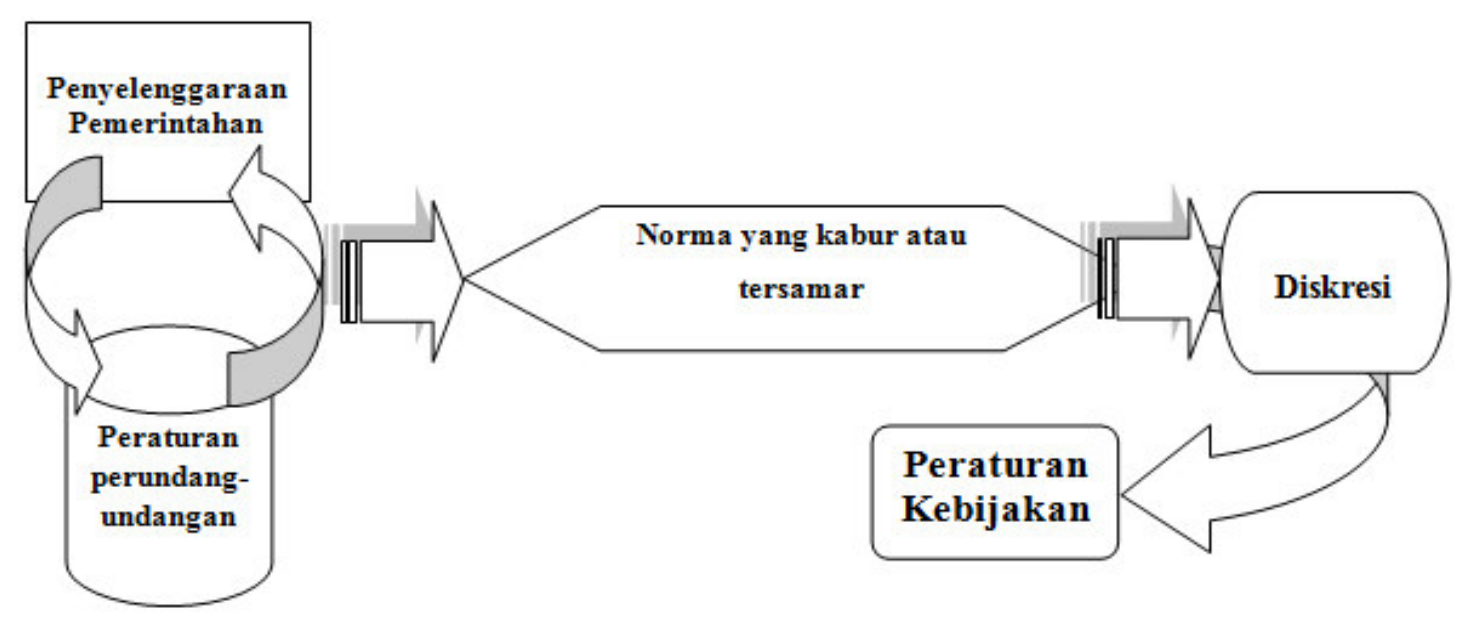

PENUTUP

Pendekatan

perbandingan

menunjukkan bahwa pengaturan

diskresi seharusnya juga diimbangi dengan pengaturan peraturan kebijakan. Pengaturan peraturan kebijakan tersebut diperlukan untuk memberikan rambu-rambu dalam pembentukan peraturan kebijakan dan bentuk-bentuk peraturan kebijakan yang digunakan. Pada praktiknya, seringkali diskresi pemerintahan menggunakan bentuk-bentuk peraturan perundang-undangan padahal pembentukan peraturan perundangundangan tersebut tidak didelegasikan oleh peraturan perundang-undangan yang lebih tinggi. Oleh karena itu, jika diatur dalam UU Administrasi Pemerintahan, diperlukan ketentuan yang mengatur bentuk-bentuk tersebut secara enumerasi. 
Tabel 1. Perbandingan Pengaturan Peraturan Kebijakan

\begin{tabular}{|l|l|l|l|}
\hline \multicolumn{1}{|c|}{ Aspek } & \multicolumn{1}{|c|}{ Belanda } & \multicolumn{1}{|c|}{ Amerika Serikat } & \multicolumn{1}{c|}{$\begin{array}{c}\text { Indonesia: } \\
\text { Rekomendasi }\end{array}$} \\
\hline $\begin{array}{l}\text { Latar } \\
\text { belakang }\end{array}$ & Norma yang kabur & Norma yang kabur & $\begin{array}{l}\text { Kekosongan hukum, } \\
\text { Norma yang kabur, } \\
\text { Stagnasi } \\
\text { pemerintahan, } \\
\text { Adanya pilihan }\end{array}$ \\
\hline Fungsi & $\begin{array}{l}\text { Interpretasi } \\
\text { peraturan }\end{array}$ & Interpretasi peraturan & $\begin{array}{l}\text { Interpretasi peraturan, } \\
\text { regulasi sementara }\end{array}$ \\
\hline Bentuk & Besluit & $\begin{array}{l}\text { Interpretative rules, } \\
\text { general statements of } \\
\text { policy, dan rules of } \\
\text { agency organization, } \\
\text { procedure, or practice. }\end{array}$ & $\begin{array}{l}\text { Juklak, juknis, surat } \\
\text { edaran, instruksi }\end{array}$ \\
\hline
\end{tabular}

Namun peraturan kebijakan sebaiknya kebijakan menjadi salah satu bentuk bukan menjadi satu-satunya tindakan diskresi, bersama KTUN maupun pemerintahan yang dapat dilakukan tindakan faktual (lihat Gambar 3). sebagai bentuk diskresi. Peraturan

Gambar 3. Alur Peraturan Kebijakan

dalam UU Administrasi Pemerintahan (Rekomendasi)

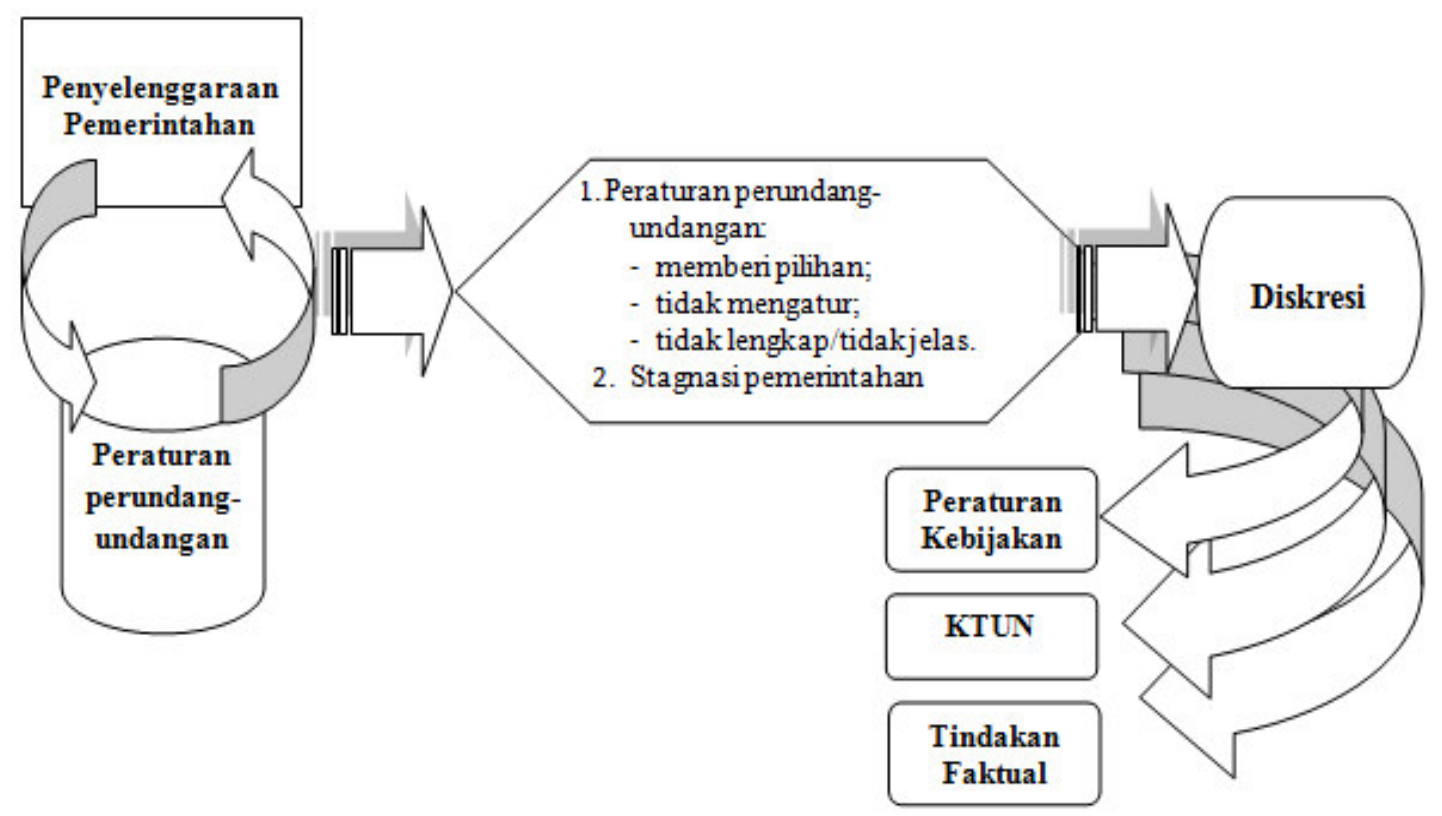




\section{DAFTAR PUSTAKA;}

\section{Buku}

Anggriani, Jum, Hukum Administrasi Negara (Graha Ilmu 2012).

Asshiddiqie, Jimly, Perihal UndangUndang (Rajawali Pers 2010).

Beermann, Jack M., Administrative Law (Aspen Publishers 2010).

Darumurti, Krisha D., Kekuasaan Diskresi Pemerintah (PT. Citra Aditya Bakti 2012).

Hadjon, Philipus M., Pengertian Dasar tentang Tindak Pemerintahan, (Djumali 1985).

Manan, Bagir, dan Kuntana Magnar, Beberapa Masalah Hukum Tata Negara Indonesia (Alumni 1997).

Vlies, I.C.van der, Buku Pegangan Perancang Peraturan Perundangundangan (Direktorat Jenderal Peraturan Perundang-undangan Departemen Hukum dan Hak Asasi Manusia RI 2005).

\section{Jurnal}

Gersen, Jacob E., 'Legislative Rules Revisited' (2007) 74 The University of Chicago Law Review 1705.

Manan, Bagir, 'Peraturan Kebijakan' (2008) Varia Peradilan 1.

Tollenaar, Albertjan, 'Soft Law and Policy Rules in the Netherlands' (2012) Netherlands Administrative Law Library 1.

\section{Pidato}

Attamimi, A. Hamid S., Hukum tentang Peraturan Perundang-undangan dan Peraturan Kebijaka (Hukum Tata Pengaturan), Pidato Purna Bakti Guru Besar Tetap Universitas Indonesia, 1993.

\section{Internet}

Anonim, 'RUU Adpem Disahkan, Tak Ada Lagi Kriminalisasi Kebijakan' (2014) <http://www.menpan.go.id/ berita-terkini / 2666-ruu-adpemdisahkan-tak-ada-lagi-kriminalisasikebijakan> diakses 19 November 2014.

\section{Lain-lain}

Kementerian Pendayagunaan Aparatur Negara dan Reformasi Birokrasi, Naskah Akademik Rancangan Undang-Undang Administrasi Pemerintahan (Kemenpan RB 2014). 
